\title{
The New 'Bond-age', climate crisis and the case for climate reparations: unpicking old/new colonialities of finance for development within the SDGs
}

\author{
Keston K. Perry (Ph.D) \\ University of the West of England (UWE Bristol) \\ Coldharbour Lane, Frenchay campus \\ Bristol, BS16 1QY \\ Keston.Perry@uwe.ac.uk
}

\begin{abstract}
In the current crisis period, the Sustainable Development Goals (SDGs) have provided a framework for new norms about governance of and access to external financing that emphasize stimulating investor interest and creating a suite of innovative instruments to address major development challenges.

However, the inadequacies associated with extant financing streams are in sharp relief since they do not address damages and losses associated with the climate crisis. The current global configuration aimed at generating from "billions to trillions" of development finance are awfully mute on historical responsibility for the uneven and extreme consequences facing climate-impacted communities in the Global South. This paper interrogates the role of the SDGs, in particular SDG17, in both adducing financialisation as an evolutionary process, further extracting profit from racialized communities, and a source of instability in the global economy. It points to the manner in which the "trillions" deemed necessary are ostensibly mobilized in pursuit of financial returns to be made from climate disaster that generate further debt, dispossesses racialized populations in the global south, and thereby ushering in a new era of "bond-age" and coloniality. Current development financing arrangements under the SDGs would increase the cost burdens and compromise the Global South's capacities to democractically manage and meet their developmental needs due to accumulating losses and damage from major extreme climate-induced events. Loss and damage compensation for marginalised developing countries at the forefront of the climate crisis must therefore come from another source: climate reparations. Climate reparations offer an appropriate encompassing philosophical and policy apparatus for first understanding the magnitude of climate breakdown, and second for mounting a response to ongoing environmental harm in vulnerable countries that is centred on climate justice.
\end{abstract}

Keywords: climate debt; Sustainable Development Goals; financialization; climate reparations; climate loss and damage; development finance 


\section{Introduction}

In 2015, the world met and thunderously welcomed the successor development targets known as the Sustainable Development Goals (SDGs) at the UN General Assemblyi. These 17 lofty goals all aimed at improving living standards and addressing myriad challenges were underpinned by an institutional framework shaped in the twilight of the global financial crisis. The global 2008 crash underscored the role that global finance and institutional investors would play in shaping the material contours of "development" in the context of intense climate instability. The ongoing reconfiguration and structure of inequalities and spatial relationships at a world scale in which bondholders, speculative traders, investment "do-gooders" were gaining influence was well underway (Christophers, 2015; Musthaq, 2020). Thus, global governance institutions such as the United Nations engaged through the SDGs in a process of 'global bricolage' in which practices of inclusion and exclusion were reified and were of primary importance to maintain certain hierarchies of power (Thérien and Pouliot, 2020). The unanimous decision of SDG adoption, in this way, may obscure the problemtatic universalist approach of neoliberal development policy that has evolved since the 1980s whereby the contested politics of decision-making structures at the global level are made invisible, relegate the global periphery and ultimately do not meet the needs of the most marginalized (Girvan, 2005; K. K. Perry, 2020a).

Since the crisis, global institutions have become more and more enthusiastic about the need to increase the global financial outlay and liquidity to achieve the global goals, through a mishmash of investor-led, debt and equity based financial instruments (United Nations, 2014; Gabor, 2020). At the Addis Abbaba Conference on Financing for Development in 2015, the United Nations resolved that the opportunity to capitalize on new flows of financing would bolster attempts to achieve the SDGs through strengthening policies and regulatory frameworks that would work towards "unlocking the transformative potential of people and the private sector 
and incentivizing changes in financing" to marshall US\$2.5 to 3 trillion per year needed especially in developing countries (United Nations, 2015a, p. 3, 2019). In practice, this complicates the view that finance was once used as a tool developmental policies and subordinated to democratic control and can now be mobilized in service of sustainable development which boosts financial interests and markets (Mawdsley et al., 2018; Gallagher and Kozul-Wright, 2019; Jomo and Chowdhury, 2019; UNCTAD, 2019). It also contests the idea developmental policies from the Global South have ever served the domestic needs of their populations (see Amsden, 2009) or have perpetuated uneven circuits of global capital that resulted in the 1980s debt crisis and whether new sources of finance could meaningfully address extreme vulnerability to climate crisis (see Ram and Donna Kaidou-Jeffrey, 2020 about this claim; García-López, 2018; Gahman and Thongs, 2019; Thomas and Benjamin, 2019; Smith-Nonini, 2020).

These institutional and economic relationships have in effect ushered a new "bond-age" and new forms of coloniality for Global South countries caught in the entangled web of macroeconomic volatility, financial dependence, climate injustices and socio-political uncertainty. I argue that the twilight of the global financial crisis has not dissipated, given the minimal role played by the global south movements in writing new reforms or rules and their unequal power in defining the global financial system. These interconnected problems are mediated by ongoing financial and climate crises that incapacitate these countries that have inadequate resources to meet basic conditions of decent life on their own terms in the context of unjust socio-ecological relations. Notwithstanding the the increasing role of global finance, for good or ill, the United Nations via the SDGs, the Paris Agreement and subsequent International Warsaw Mechanism for Loss and Damage have not instituted a viable compensatory mechanism for the slow, extreme or violent throes of the climate catastrophes and socio-ecological harm visited upon climate-vulnerable countries (Gewirtzman et al., 2018; Dehm, 2020). No specific and targeted 
international funding mechanism and safety valve to meet these massive losses and damages exist. In this scenario, finance operates as an entanglement of power relations accruing rent from climate devastation and untethered from specific broad development aims democratically determined by peoples in the Global South - returning us close to the period of colonialization under new guises and spatial orientations. This essay thus argues that a program of compensation for loss and damage do not fit within current global mechanisms and structures, and must be created anew based on political acknowledgement of differentiated responsibilities and impacts. Climate reparations must therefore serve as a starting point for upending the racialized nature of climate disaster due to colonial legacies of environmental degradation, destruction and dispossession and premised on political mobilization and recognition at various scales of struggle and endeavour.

\section{Finance for development and the SDGS}

In development theory and analysis, scholarly and policy focus has shifted to increasing the sources, instruments and modalities of capital flowing to developing countries. This new era of courting finance, first set in motion through financial liberalization policies had been deemed necessary to remove the supposed strictures on capital movements, high reserve requirements, and quantitative limits in the credit allocation system after the postwar period of financial regulation and Keynesian management (Shaw, 1973; Fry, 1978; McKinnon, 2010). The financial repression theory thus developed to explain that non-market mediated interest rates prevented monetary authorities and policy makers from understanding the "true" scarcity of capital in the economy. In this perspective, capital has become considered a scarce commodity. As a result of government intervention, in the view of some mainstream scholars and institutional actors, the capital-generating capacity of developing countries has been constrained and interventionist efforts have largely failed to narrow the income gap with advanced industrialised economies (Buera, Kaboski and Shin, 2011). 
Other economists have challenged this perspective suggesting instead that the availability of finance for economic development increases as the development process unfolded rather than the other way around (Arestis and Basu, 2008; Ffrench-Davis and GriffithJones, 2019). As the result of banking and financial crises across developing countries since the 1980s, they suggest that the channels of financial liberalization, and now financialization ${ }^{\text {ii }}$, have instead undermined development through macro-economic stability and incapacity to direct needed resources and credit to developmental purposes (Arestis, 2016; Alves and Toporowski, 2019). In Sub-saharan African and Latin American countries, some literature have reported limited causal relationship between liberalization, increased capital movements and broad productive development due to lack of long-term investment and financing of domestic firms (Crespi, Tacsir and Vargas, 2016; Njikam, 2017; Kvangraven, Koddenbrock and Sylla, 2020). Financial opening mechanisms have instead emphasized reregulation of markets to enable firms to access derivative markets, and private investors more leeway to pour on additional debt that have limited development possibilities.

Since the earlier period of financial liberalization, we can see the increased presence of external financial actors especially in the first place multilateral development institutions that opened up capital accounts and domestic financial sectors to international competition and intrusion of a host of financial interests (Kaltenbrunner and Karacimen, 2016; Fine and Pollen, 2018). In particular the World Bank's 'Maximising Finance for Development' initiative promoted increasing public-private engagement in infrastructure, education and healthcare provision, as well as reform initiatives that increased private financial provision in traditional as well as new market-based lending (Jomo and Chowdhury, 2019; Gabor, 2020).

Moreover, the designation of the Millennium Development Goals (MDGs) in the early 2000s, development projects and new financing sources were aimed at sourcing additive finance in place of traditional overseas aid towards promoting equity, economic transformation 
and sustainable development (Girishankar, 2009; Corrado and Corrado, 2017). Signs of this evolutionary shift in finance are seen as development conferences framed the environmental and development problems. At the UN Conference on the Environment and Development in 1992, this recognition was made:

'The development process will not gather momentum if the global economy lacks dynamism and stability and is beset with uncertainties. Neither will it gather momentum if the developing countries are weighted down by external indebtedness, if development finance is inadequate, if barriers restrict access to markets and if commodity prices and the terms of trade of developing countries remain depressed' (United Nations, 1992, p. 4).

Under the MDGs, global estimates for meeting targets for expanding drinking water and sanitation stood at $\$ 13$ and $\$ 17$ billion per year respectively which did not immediately consider the costs associated with building new infrastructure, operational improvements, and sector development (Mehta, Fugelsnes and Virjee, 2005). Overseas Development Assistance (ODA) or 'foreign aid' requirements for Organisation for Economic Cooperation and Development (OECD) countries to meet their 0.7 per cent of gross national income target in addition to debt relief formed integral sources of finance under the MDGs (Mawdsley, 2018). These arrangements were deemed insufficient as non-governmental and foreign aid sources could not deliver and so required private sector input. The take-off of public-private partnerships in water, health and other sectors increased the private stake in public goods provision but also increased the fiscal risk to developing country governments (Bayliss and Waeyenberge, 2018). In 2002, the Monterrey Financing for Development conference proposed a number of concrete commitments to finance the MDGs. These included: 
- A commitment to mobilising government revenue through 'effective, efficient, transparent and accountable systems for mobilizing public resources and managing their use by Governments', including 'equitable and efficient tax systems and administration' (para 15)

- A commitment to provide more aid to support the MDGs, by urging developed countries to allocate $0.7 \%$ of their GNI to aid and $0.1-0.2 \%$ to aid to least developed countries (LDCs) (para 42)

- A commitment to increase the effectiveness and results of aid, notably by supporting 'development frameworks that are owned and driven by developing countries' (para 43)

- Exploring the use of 'innovative finance' to supplement ODA

- Balancing the provision of new 'sustainable debt financing' and debt relief

- Commitments to support national development efforts with 'an enabling international economic environment' (para 6), including 'the use of ODA to leverage additional financing for development, such as foreign investment, trade and domestic resources' (para 43).

Source: (Development Finance International and Oxfam, 2015, p. 32)

The evolution of finance has taken on a new urgency as calls are made for rapid expansion under the SDGs. The post-2015 development agenda sought additional overseas aid and to initiate a greater thrust for attracting private foreign investment, other financial instruments and sources of capital:

'the multilateral development banks and other international development banks to continue providing both concessional and non-concessional stable, long-term development finance by leveraging contributions and capital and by mobilizing resources from capital markets, and stresses that development banks should make optimal use of their resources and balance sheets, consistent with maintaining their financial integrity' (United Nations, 2015b, p. 7).

Financiers have trained their sights not only on poverty, education, health and so on (so-called traditional areas of development intervention) but climate action and the environment that risk driving up short terms profits and capital gains of top income earners (Ghosh, 2015). To respond to these challenges 'innovative finance' according to the United Nations include a 
number of potentially supplemental instruments that included blended finance, equity loans and bonds that would be geared towards US\$12 trillion of market opportunities, and generate potential savings of about US $\$ 26$ trillion by 2030 which all made up the discussions in Addis Ababa (United Nations, 2014, 2015a, 2019; Barua, 2020). In the process to devise new financing arrangements, developing countries were however largely marginalized in the Addis Ababa Financing for Development framework especially small islands nations such as those in the Caribbean which are considered middle income. Despite these countries' continued marginalization in the global economy and extreme exposure to climate change, they no longer qualify for concessional loans or ODA financing, and fiscal resources were tied up to debt payments and servicing to meet their own development challenges (Bourne, 2015; Brissett, 2018).

When we consider major issues in the SDGs like poverty, especially the environmental dimensions of poverty, Antoniades et al (2019) found that systemic financial distress are associated with increases in the incidence of poverty to meet many of the targets of the SDGs and could result in furthe increases in carbon emissions and commodification of forests ${ }^{\mathrm{iii}}$. They assert that financial crises in which many developing countries are currently found, have an adverse impact at the macro-level on government's ability to pursue these goals and at the micro level on households' resilience (Antoniades, Widiarto and Antonarakis, 2020). Hence, enduring systemic vulnerabilities weaken the resource and fiscal outlay and capacity of both households and the state. In addition, the intentional and uneven integration of developing countries in the global financial system have resulted in increasing debt and financial speculation in developing countries that contribute to perennial vulnerabilities (UNCTAD, 2018; Kvangraven, Koddenbrock and Sylla, 2020; K. K. Perry, 2020c). Debt accumulation and servicing costs constitute obstacles to achieving the SDGs and finding appropriate financing mechanisms that support development have been subsumed under current neoliberal discourses about innovative financing. The reasons of structural dependence on capitalist core 
economies on capital and for demand of raw materials that underlie the 'origin story' of development and maldistribution of resources in the global economy have longstanding economic and political sources (Rodney, 1972; Girvan and Girvan, 1973; Amin, 1977). These factors that exacerbate misery and financial subordination and generate uneven geographies of devastation can be seen as continuity rather than major change in conditions.

Besides, the economic and political constructions of development finance and the SDGs are also defined by geographies of social and economic difference, and the locations where racially stratified and defined groups of people are, and their relationship to the power centers in the global economy. Developing countries after the Second World War were believed to have started with a tabla rasa with respect to conditions for their social progress. The goal of development here was therefore to deliver certain human rights, markets and equality as universally defined and deemed worthy (Shilliam, 2014; Tilley and Shilliam, 2018). With the SDGs in mind, this idea has remained relatively unchanged insofar as so-called innovative financial and economic instruments are justified and the Global South remain testing spaces where they can be deployed with maximum effect. Accordingly, this kind of "odious debt" as put forward by Peter Hudon, has always been a part of the reality of countries in the global south ever-present racial and imperial subordination, and formed part of the way in which the global south was integrated in the global economy through colonialism, structural adjustment and now financialisation (Hudson, 2017; Bhambra, 2020). These geographies of difference help determine how capital targets racialized communities including the social and spatial relations, labor regimes, and specific practices of organizing under capitalism (Bledsoe and Wright, 2019). The SDGs financial framework thus represent existing assymetries of resources and power, new forms of coloniality, and political status. Historical goals of repair which any "development" agenda might address and have been neglected are ineluctably connected to lack of financial wherewithal and climate destabilization. 
Financializing development and global climate finance: the loss and damage gap

Even though the "billions to trillions" agenda under the SDGs endeavour to bridge the gap in capital flows to developing countries (Vos, 2017), enduring problems, new forms of coloniality and the perils of financializing the climate emerge (Bracking, 2019; UNCTAD, 2019). The private finance agenda under the SDGs are at the base of these problems. In this section, I explore these tensions and challenges by offering an overview of the climate finance landscape and zoning in specifically on the loss and damage category that have been at the centre of battles in international climate politics over the last decade, with no clear resolution in sight. The SDGs and its financial framework represent thus a marked evolution in the capitalist process towards ever increasing forms of financial intervention and extraction with particular attention to new financing arrangements and enclosures that move away from ODA, public finance and domestic resource mobilization towards more emphasis on bonds, derivatives, blended finance and debt (UNCTAD, 2019). Within the UN system, where these interventions and deliberations were made, what is omitted or deemed relevant determines who should benefit and the ways in which these benefits are appropriated across communities, sectors and specific priorities.

Climate finance ${ }^{\text {iv }}$ in this way have formed the new infrastructures around which these issues can be understood (Christophers, 2017). This is particularly acute as we consider current and evolving relationships for climate finance that seeks to address reducing greenhouse gas emissions and helping marginalized countries to adapt or mitigate the effects of ever unfolding and violent climate change and devastation. In 2009, countries met as part of the UN Framework on Climate Change (UNFCC) and pledged to raise $\$ 100$ billion annually up to 2020 to address and later set up the Green Climate Fund as a mechanism to administer and disburse these funds. The current framework of climate finance was established within the Paris Agreement which has placed a heavy emphasis on mitigation given the role that advanced industrialised countries have played in global climate politics (Abadie, Galarraga and Rübbelke, 
2013; Campagnolo and Davide, 2019; Khan et al., 2019). Decarbonisation, or mitigation goals, has been are a primary focus of the North Atlantic countries given the uneven spatial impacts of the climate crisis on the social economies of Europe and North America which have been able to withstand climate shocks despite their huge financial costs (CRED and UNDRR, 2020). In the meanwhile, Global South countries have been less successful at internalizing these costs (Khan et al., 2019). The onset of ever more ferocious typhoons, storms, longer droughts, and flooding have placed climate adaptation and losses and damage as central concerns for lesser industrialized countries which have limited fiscal capacity to recover and rebuild.

In this manner, evincing mitigation bias in climate policy, significant financial flows have targeted improving and expanding renewable energy generation, land use and energy efficienc that have achieved on average USD537 billion or 93 per cent of climate finance (Buchner et al., 2019). The OECD estimates that US $\$ 71.2$ billion in public finance for climate change actions were raised in 2017, up from USD 58.6 billion in 2016 by industrialized and developing countries that represents a significant shortfall of the US $\$ 100$ billion target (OECD, 2019). In comparison, adaptation finance averaged USD30 billion or 5 per cent of climate flows. Bilateral and multilateral financing have also increased to around US $\$ 58$ billion and US $\$ 26$ billion (an increase of USD7 billion and USD11 billion respectively) (Buchner et al., 2019). Recent documentation shows that the most vulnerable countries receive smaller funding contributions for adaptation from bilateral and multilateral donors than their less vulnerable counterparts (Saunders, 2019). In the Caribbean sub-region, consisting some of the most vulnerable countries in the world to increasing incidence of major storms, coral bleaching and ocean acidification, only 32 per cent of funding is allocated to adaptation, compared to 48 per cent for mitigation (Atteridge, Savvidou and Canales, 2017) ${ }^{v}$. These differentials show the continuing injustice in the current system of climate finance that marginalize countries most at need but also the ways in which investors are more interested in high-yielding disaster portfolios. 
In 2007, the Caribbean Catastrophe Risk Insurance Facility (CCRIF) was set up and operates as a risk transfer mechamism which mixes parametric risk insurance and regional risk pooling across governments $\mathrm{s}^{\mathrm{vi}}$. It is believed that sovereign risk transfer offers an important intervention whereby country governments can manage their exposure to major extreme weather events by spreading the risk over long periods across the region. This mechanism paid out US $\$ 130.5$ million up to 2018 to several island territories, and essentially became a way for communities and states already facing high debt burdens and constrained fiscal space to absorb a large proportion of losses, exacerbating conditions of vulnerability and marginalisation (Christophers, Bigger and Johnson, 2020; K. K. Perry, 2020b).

Loss and damage concerns are relgated in the political economy of climate finance due to the lack of interest especially in the United States (Khan et al., 2019), despite the most marginalized countries and populations making claims on the international community to meet these costs in the spirit of "common and differentiated responsibilities" (Thomas and Benjamin,

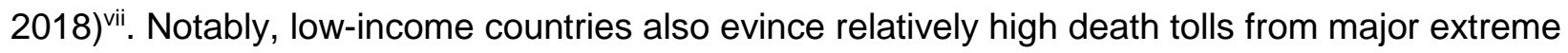

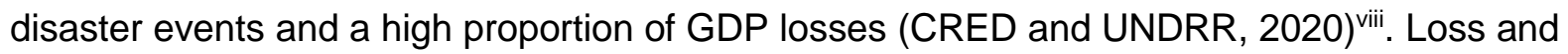
damage costs have ballooned over the last two decades but are not featured in the flows of climate finance. Conservative estimates suggest they amount to in excess of USD 500 billion yearly up to 2030 , or make up 33 per cent of economic costs associated with extreme weather events (Richards and Schalatek, 2018; CRED and UNDRR, 2020). The Human Costs Report also noted that lower-middle and upper-middle income countries make up most disaster events, deaths, and total people affected. Global financial institutions and even the UN have continued to pay lip service, and in the case of the International Monetary Fund, have piled on additional debt seen recently in the Bahamas and Mozambique to satisfy the appetite of global investors (IMF, 2019; K. Perry, 2020). Global financial institutions continue to ignore the racialized and historical nature of these disasters and have so far been uninterested in seriously addressing 
such claims. Therefore, additive finance must come through a programme of repair specifically aimed at addressing longstanding inequities associated with climate change.

Another instrument, climate for debt swaps are proposed by a number of scholars at universities in the Global North as well as international institutions as a market-based solution ${ }^{\text {ix }}$. ECLAC's approach suggests that sovereign debts of heavily indebted countries that have a large pool of private creditors would undergo a repurchase, and debt swap mechanism would be applied (ECLAC, 2020). In this view, debt repayments from Caribbean or other highly indebted countries would be deposited in a fund which would be administered or managed by a third party and earmarked for resilience initiatives to help fund adaptation or mitigation-focused green industrial projects (ECLAC, 2020; Steele and Patel, 2020). However, UNCTAD (2019: 93) has pointed out these debt swaps function on a costly and sluggish contract-by-contract basis and prioritise creditors over sovereign debtors, whereby debts would be procured at already critical times to ensure relatively high discounts. More than this, there is no guarantee that there will be any clear compulsion to follow through on any environmental objective to the benefit of the country involved. As been shown elsewhere (Perry 2020c), external funders demands often take priority to local populations' long-term welfare and development needs.

To support African countries' renewable energy transition which would require Africa's energy sector to seek average annual investment of US $\$ 70$ billion of investment to $2030^{\times}$based on new private financing as well as loans (IRENA, 2020). The report also noted that over the period of the MDGs, ODA flows to Sub-Saharan Africa on energy increased by six times between 2003 and 2016 from around USD750 million to USD4.7 billion (IRENA, 2020, p. 23). Africa still has energy poverty among 650 million people (IRENA, 2020). Gujba et al. (2012) suggested that in order to realise modern energy services, a range of financing instruments and opportunities could help fill the gap, including a number of multilateral grants, co-financing, loans, equity (ODA), technology cooperation mechanisms, among others. They further suggest that greater attention could be placed on domestic taxation and levies on households and 
industry for fossil fuel and electricity use, as well as subsidy reductions (Gujba et al., 2012). In the Caribbean region which has some of the highest rates of electricity based on its dependence on imported, financing from multilateral and private sources contined to dominate energy provision (Atteridge and Savvidou, 2019).

Given these situations and the role that climate finance has played in the broader development finance policy debates, especially under the conditions of worsening climate crisis, one cannot ignore how these emerging relationships of multilateral and private creditors and grantees of external financing mirror colonial relationships (Best and Levitt, 2009). Financializing climate catastrophes have become the new source of rewards for global investors (Christophers, Bigger and Johnson, 2020), as they calculate risks into the future and even as the problem of extreme vulnerability is cumulative through time and with differentiated spatial configurations. Countries which seek to sidestep these harmful rules of finance and their colonialites associated thereto are punished from their exclusion from capital markets and sources of new finance. Starting with the entanglements of colonialism and capitalism and the making of the world after the Second World War, the current climate finance landscape has evolved to imbibe the current historical moment of development finance and financialisation and have limited the resources available to meaningfully and viably address these problems. Therefore, we must look to another source for recompense and restitution for these ongoing extremes.

\section{The case for climate reparations}

The 2017 Atlantic Hurricane witnessed major calamity in the region, where Hurricanes Maria and Irma caused upward of US\$5.4 billion in damage and losses to five of the affected islands $^{x i}$ (ECLAC, 2018). Approximately 134 people were estaimated to have lost their lives during these disasters, which Norman Girvan labeled as "existential threats". The costs of these 
disasters, while often seen as "natural" offshoots of worsening climate change, represent cumulative effects of racialization and social difference borne and exacerbated through material and physically altering processes of colonization and pattern of global market integration and accumulation. It is from this basis that the SDGs' neglect or indifference towards racialized hieracrhies within the global economy while even adopted during the "decade of People of African Descent" (2015-2024) is not accidental. A cogent case for reparations for climate injustices against further attempts to put countries in debt through new forms of development and climate finance through the "from billions to trillions agenda" is apt. The neglect of losses and damage at the global level in climate politics to permanently defer responsibility for climate injustice (Thomas and Benjamin, 2019; Dehm, 2020). This neglect stems from a process that evinces why societies in the Global South, especially island communities, are overlooked racialized zones of surplus populations yet spaces for new global accumulation and bond-age.

We can see this play out in the Caribbean region, where extreme examples of climate devastation are well known that shows continued dispossession, and new financial instruments, blue economy narratives of capitalizing the ocean, and debt through bonds are being deployed and experimented with (see Ram and Donna Kaidou-Jeffrey, 2020). As a result of Hurricane Irma, Sint Maarten suffered estimated costs amounted to more than US $\$ 2$ billion, including direct physical damage and losses of revenue and other sources of income (Collodi et al., 2019). Hurricane Irma damaged 70 per cent of all structures and was directly responsible for four deaths on the island. Considered fiscally independent up to that point, the island was forced into a renewed financial dependent relation with Dutch authorities who assured EUR 550 million to help rebuild the island whose disbursement was managed by the World Bank on behalf of the Dutch government and tightly monitored toavert corruption (Collodi et al., 2019). Similarly in Barbuda, Irma inflicted estimated losses and damages amounting to US\$155 million, destroyed 95 per cent of property and made internal refugees of 1700 residents of Barbuda who had 
claims to communal land on the island (UNDP, 2018; Baptiste and Devonish, 2019).

Nonetheless, Barbudans returned to the island to 'make do' with their current misfortune and challenge both profit-generating attempts by government and external financiers to take possession of the island through quasi-legal means (Lightfoot, 2020). In the Bahamas, where major islands Grand Bahama and the Abaco Islands were devastated after Category 5 Hurricane Dorian spent almost forty hours hovered over the island with winds of 185 miles per hour, losses and damages accumulated to more than US\$3.4 billion and claimed dozens of lives (IDB, 2019). Over US\$300 million in additional public debt has resulted with a cost of more than $27 \%$ to its GDP, thereby leaving its public finances in major straits (K. Perry, 2020).

While the Northern and Leeward Caribbean islands have intense exposure to Atlantic storms, low-lying regions in Southern territories like Guyana and Trinidad and Tobago that have been characteristically outside of the Atlantic hurricane. They have nonetheless incurred major physical and human damage to agriculture and infrastructure from recent extensive flooding events in 2015 and 2017 affecting over 150,000 and 202,274 people and equivalent to millions in damage (K. K. Perry, 2020b). These immediate estimates do not consider the long and effects to major tourism industries, coastal erosion and higher seal-level rise have on communities that have long been sites of resource extraction, surplus populations and racialized derpivation and debt (Heger, Julca and Paddison, 2008; Sealey-Huggins, 2017). Amongst these islands, Haiti features prominently as a site of repeated devastation from major Hurricanes such as Matthew in 2016 that caused over $\$ 3$ billion in infrastructure damage, major losses to farmers and communities and households left without means of income or food provisions for multiple weeks (Sheller, 2018; K. K. Perry, 2020a). These economic costs also do not take account of the "interconnected crises that plague people's existence" that result in extended displacement of entire island populations due to complete decimation of communities, loss of sense of place, long-term effects on the insular landscape and environmental precarity, feelings 
of injustice, resulting community loss, abandonment and trauma (Thomas and Benjamin, 2019; Welcome, 2020). These episodes represent racialized deprivation and coloniality due in part to socio-ecological crisis and external intervention. These island communities thus have a claim for reparatory justice due to out of control debt after disasters, imposed austerity and various forms of foreign intervention linked to their colonial foundation as an extractive economy.

Unlike marginalized cities in the Global North suffering from their own forms deindustrialization and dispossession, the Global South have long been sites of neoliberal experimentation and practice, to which investors have flocked in times of boom (Pulido, 2016; Bigger and Millington, 2020). According to Tilly (2020), we can consider these sites as created as "productions of investibility" that are critical for ensuring global market integration and that enable value extraction on terms that reinforce herarchies of productive and financial power within the global market system that facilitate value extraction for investors (Antoniades, 2013; Bonizzi, Kaltenbrunner and Powell, 2019). Bondholders increasingly have borderless influence in the environmental domain (Christophers, 2017; Bigger and Millington, 2020). Deemed emerging markets, such a construction has a dual functions, as monikers of optimism and inclusion within the new global divide of who receives mobile investments, and who does not, in response to extraction and climate change (Bigger and Millington, 2020; Tilley, 2020). For instance, green bonds in South Africa have become major tools to distribute financial and environmental risk away from the capital owners and towards cities and municipal authorities in the Global South and increases dependence on capital markets (Bigger and Millington, 2020). The "billions to trillions" agenda promoted through the SDGs are therefore not sources of emancipation for mitigating against the already occurring violent effects of climate catastrophe, but rather further bounding countries' governments, and by extension their populations, to increased and diversified sources of new risk that paralyse their ability to respond to climateinduced dispossession and disaster. 
Structural adjustment, austerity and debt crises of the 1980s and 1990s in many countries in the Global South continue to play out as neoliberalism evolves to redirect capital and financialize nature and create new forms of dispossession and fracture socio-natural relations (Gahman and Thongs, 2019; Sheller, 2020). For the Caribbean islandscapes, colonial culprits are duly unmasked by "the persistent loss of black life and the dereliction of poor people's materialism in a backward built environment that was designed for the sole purpose of of servicing imperial sugar plantations reside squarely at the core of their respective metropolitan capitols" (Beckles, 2017). These peoples are means of just repair or response to these multiple intersecting calamities. According to Pulido (2016) state laws become ineffectual in addressing injustices inherent in sacrosanct contracts with bondholders whose status can be seen as a serious incursion on the social relationships between people and the environment. Under contemporary capitalism, such surplus populations embody varying degrees of integration into labour markets, whether as precariously employed as known through informal contracts or certain kinds of informal labour relations such as self-employment or permanent unemployment.

The justificatory position for claiming and making demands for climate reparations based on histoire raisonnée attributing responsibility to former and current imperial powers based on greenhousegas emissions (Ritchie and Roser, 2017). Their critical role is also clear in dermarcating racial difference that determines economic well-being that contributes to the uneven geographies of climate disaster (Moulton and Machado, 2019; Sheller, 2020). Both within countries and across countries, development finance initiatives, including climate finance are creating new surplus populations tied to new bondages and colonialities. The lack of inclusion or disregard of this reparatory agenda at the level of the SDGs seems critical to understand why current financing agendas to address mitigation and adaptation challenges are inadequate. The "inclusive partnership" envisioned by SDG17 must therefore make room for 
based on pledges of charity or increased overseas aid which are based on voluntary contributions, quid pro quos and technical policies. Remedying damages and losses through a reparatory agende are at the centre of climate justice for those made vulnerable through imperial designs, deliberate historical acts, disregard and even industrial violence. Justice in the face of a violent climate crisis can only be met by shattering these colonialities and returning countries to a position before the socio-ecolological harm.

\section{Conclusion}

Even in the face of the current global crisis that have dried up tourist dollars, curtailed exports of primary goods, and created economic distress in many marginalized, low income and Small Island territories are facing extremely intense hurricanes. 2020 has produced upward of 30 Altantic storms of which 13 progressed to hurricanes that have battered several Central American and Caribbean countries and displaced large numbers of people. Many of these ‘middle-income' countries may not 'qualify' for debt forgiveness, liquidity overtures, or global safety net provisions requested by the United Nations (United Nations, 2020). The SDGs' silence on reparations for climate devasatation, even though the UN has offered muted calls for reparatory justice for people of African descent, indigenous communities for current harms and discriminations within the International Decade of People of African Descent (IDPAD - 2015-

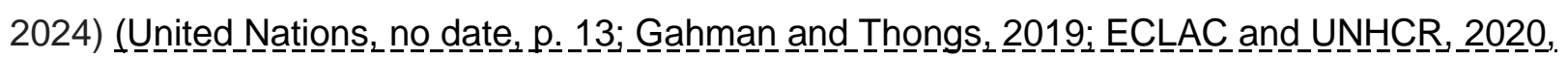
p. 21) appear contradictory. Though the IDPAD resolution was decided at the United Nations in 2013 and implemented the same year the SDGs were adopted, and even acknowledges the need to strive for equality under the SDGs, it offers technocratic solutions such through strengthening mechanisms of data gathering and developing new indicators to measure inequalities and gaps of people of African descent, (ECLAC and UNHCR, 2020, p. 8). It is evident that the IDPAD and the Finance for Development or "from billions to trillions" SGDs 
agenda are thus discrete endeavours (Multilateral Development Finance Committee, 2015). The call for new metrics thus show us how the technologies of coloniality can be adopted and utilized even in service of "development". This present paper thus argues that climate devastation would constitute potential area for reparations based on current or future such incidents/needs at a global level. Financial repair and a broader reparatory framework is not currently on the agenda to address climate crisis that perennially affect racialized communities in the Global South. Such claims must be made visible through transnational organising and dialogue that centre experiences and aspirations of dispossessed communities. The urgency of climate reparations becomes ever more present based on transnational solidarity and movement-building to stave off neoliberal delusions of "green recovery" currently bandied about by Global North politicians and global institutions. For many in the Global South, a return to" normal life" under financial capitalism and climate destabilization is not possible, or just. 


\section{References}

Abadie, L. M., Galarraga, I. and Rübbelke, D. (2013) 'An analysis of the causes of the mitigation bias in international climate finance', Mitigation and Adaptation Strategies for Global Change, 18(7), pp. 943-955. doi: 10.1007/s11027-012-9401-7.

Alves, C. and Toporowski, J. (2019) 'Growth of international finance and emerging economies: Elements for an alternative approach', PSL Quarterly Review, 72(288), pp. 3-26. doi:

10.13133/2037-3643_72.288_1.

Amin, S. (1977) Unequal Development: An Essay on the Social Formations of Peripheral Capitalism. Monthly Review Press.

Amsden, A. H. (2009) Escape from Empire: The Developing World's Journey through Heaven and Hell. MIT Press.

Antoniades, A. (2013) 'Recasting the Power Politics of Debt: structural power, hegemonic stabilisers and change', Third World Quarterly, 34(2), pp. 214-232. doi:

10.1080/01436597.2013.775780.

Antoniades, A., Widiarto, I. and Antonarakis, A. S. (2020) 'Financial crises and the attainment of the SDGs: an adjusted multidimensional poverty approach', Sustainability Science, 15(6), pp. 1683-1698. doi: 10.1007/s11625-019-00771-z.

Arestis, P. (2016) 'Financial Liberalization, the Finance-Growth Nexus, Financial Crises and Policy Implications', in Arestis, P. and Sawyer, M. (eds) Financial Liberalisation: Past, Present and Future. Cham: Springer International Publishing (International Papers in Political Economy), pp. 1-42. doi: 10.1007/978-3-319-41219-1_1.

Arestis, P. and Basu, S. (2008) 'Role of Finance and Credit in Economic Development', in Chapters. Edward Elgar Publishing. Available at:

https://ideas.repec.org/h/elg/eechap/3813_20.html (Accessed: 11 September 2020).

Arestis, P. and Sawyer, M. (2005) 'Financial Liberalization and the Finance-Growth Nexus: What Have We Learned?', in Arestis, P. and Sawyer, M. (eds) Financial Liberalization: Beyond Orthodox Concerns. London: Palgrave Macmillan UK (International Papers in Political Economy Series), pp. 1-42. doi: 10.1057/9780230522381_1.

Atteridge, A. and Savvidou, G. (2019) 'Development aid for energy in Small Island Developing States', Energy, Sustainability and Society, 9(1), p. 10. doi: 10.1186/s13705-019-0194-3.

Atteridge, A., Savvidou, G. and Canales, N. (2017) 'Climate finance in the Caribbean region's small island developing states'. Available at: https://www.sei.org/publications/caribbean-climatefinance/ (Accessed: 21 February 2020).

Baptiste, A. K. and Devonish, H. (2019) 'The Manifestation of Climate Injustices: The PostHurricane Irma Conflicts Surrounding Barbuda's Communal Land Tenure', Journal of Extreme Events. doi: 10.1142/S2345737619400025.

Barua, S. (2020) 'Financing sustainable development goals: A review of challenges and mitigation strategies', BUSINESS STRATEGY \& DEVELOPMENT, 3(3), pp. 277-293. doi: https://doi.org/10.1002/bsd2.94. 
Bayliss, K. and Waeyenberge, E. V. (2018) 'Unpacking the Public Private Partnership Revival', The Journal of Development Studies, 54(4), pp. 577-593. doi:

10.1080/00220388.2017.1303671.

Beckles, H. (2017) 'Irma-Maria: A Reparations Requiem for Caribbean Poverty'. Available at: https://www.mona.uwi.edu/marcom/newsroom/entry/6762 (Accessed: 18 July 2020).

Best, L. and Levitt, K. (2009) Essays on the Theory of Plantation Economy: A Historical and Institutional Approach to Caribbean Economic Development. University of West Indies Press.

Bhambra, G. K. (2020) 'Colonial global economy: towards a theoretical reorientation of political economy', Review of International Political Economy, 0(0), pp. 1-16. doi:

10.1080/09692290.2020.1830831.

Bigger, P. and Millington, N. (2020) 'Getting soaked? Climate crisis, adaptation finance, and racialized austerity', Environment and Planning E: Nature and Space, 3(3), pp. 601-623. doi: $10.1177 / 2514848619876539$.

Bledsoe, A. and Wright, W. J. (2019) 'The anti-Blackness of global capital', Environment and Planning D: Society and Space, 37(1), pp. 8-26. doi: 10.1177/0263775818805102.

Bonizzi, B., Kaltenbrunner, A. and Powell, J. (2019) Subordinate financialization in emerging capitalist economies, Greenwich Papers in Political Economy. 23044. University of Greenwich, Greenwich Political Economy Research Centre. Available at:

https://ideas.repec.org/p/gpe/wpaper/23044.html (Accessed: 25 March 2020).

Bourne, C. (2015) Financing for Development Challenges in Caribbean SIDS: A Case for Review of Eleigibility Criteria for access to concessional financing. Port-of-Spain: UNDP Trinidad and Tobago. Available at:

https://www.latinamerica.undp.org/content/rblac/en/home/library/poverty/financing-fordevelopment-challenges-in-caribbean-sids--a-case-f.html (Accessed: 20 November 2020).

BP (2019) BP Energy Outlook 2019 edition. London, UK: BP Plc. Available at: https://www.bp.com/content/dam/bp/business-sites/en/global/corporate/pdfs/energyeconomics/energy-outlook/bp-energy-outlook-2019.pdf.

Bracking, S. (2019) 'Financialisation, Climate Finance, and the Calculative Challenges of Managing Environmental Change', Antipode, 51(3), pp. 709-729. doi: 10.1111/anti.12510.

Brissett, N. O. M. (2018) 'Sustainable Development Goals (SDGs) and the Caribbean: Unrealizable promises?', Progress in Development Studies, 18(1), pp. 18-35. doi: $10.1177 / 1464993417734440$.

Buchner, B. et al. (2019) Global Landscape of Climate Finance. London: Climate Policy Initiative. Available at: https://climatepolicyinitiative.org/wp-content/uploads/2019/11/2019Global-Landscape-of-Climate-Finance.pdf (Accessed: 20 February 2020).

Buera, F. J., Kaboski, J. P. and Shin, Y. (2011) 'Finance and Development: A Tale of Two Sectors', American Economic Review, 101(5), pp. 1964-2002. doi: 10.1257/aer.101.5.1964. 
Campagnolo, L. and Davide, M. (2019) 'Can the Paris deal boost SDGs achievement? An assessment of climate mitigation co-benefits or side-effects on poverty and inequality', World Development, 122, pp. 96-109. doi: 10.1016/j.worlddev.2019.05.015.

Christophers, B. (2015) 'Geographies of finance II: Crisis, space and political-economic transformation', Progress in Human Geography, 39(2), pp. 205-213. doi:

$10.1177 / 0309132513514343$.

Christophers, B. (2017) 'Climate Change and Financial Instability: Risk Disclosure and the Problematics of Neoliberal Governance', Annals of the American Association of Geographers, 107(5), pp. 1108-1127. doi: 10.1080/24694452.2017.1293502.

Christophers, B., Bigger, P. and Johnson, L. (2020) 'Stretching scales? Risk and sociality in climate finance', Environment and Planning A: Economy and Space, 52(1), pp. 88-110. doi: $10.1177 / 0308518 \times 18819004$.

Collodi, J. et al. (2019) 'How do you build back better so no one is left behind? Lessons from Sint Maarten, Dutch Caribbean, following Hurricane Irma', Disasters, n/a(n/a). doi: https://doi.org/10.1111/disa.12423.

Corrado, G. and Corrado, L. (2017) 'Inclusive finance for inclusive growth and development', Current Opinion in Environmental Sustainability, 24, pp. 19-23. doi:

10.1016/j.cosust.2017.01.013.

CRED and UNDRR (2020) Human Cost of Disasters: An Overview of the Last 20 years (20002019). United Nations. Available at: https://www.undrr.org/publication/human-cost-disastersoverview-last-20-years-2000-2019 (Accessed: 25 October 2020).

Crespi, G., Tacsir, E. and Vargas, F. (2016) 'Innovation Dynamics and Productivity: Evidence for Latin America', in Inter-American Development Bank, Grazzi, M., and Pietrobelli, C. (eds) Firm Innovation and Productivity in Latin America and the Caribbean: The Engine of Economic Development. New York: Palgrave Macmillan US, pp. 37-71. doi: 10.1057/978-1-349-581511_2.

Dehm, J. (2020) 'Climate change, "slow violence" and the indefinite deferral of responsibility for "loss and damage"', Griffith Law Review, 0(0), pp. 1-33. doi: 10.1080/10383441.2020.1790101.

Development Finance International and Oxfam (2015) Financing the Sustainable Development Goals: Lessons from government spending on the MDGs. Research Report. Nairobi, Kenya: Oxfam. Available at: https://www-cdn.oxfam.org/s3fs-public/file_attachments/rr-financingsustainable-development-goals-110615-en.pdf (Accessed: 20 November 2020).

ECLAC (2018) 'Irma and Maria by Numbers', Focus: ECLAC in the Caribbean. Available at: https://repositorio.cepal.org/bitstream/handle/11362/43446/1/FOCUSIssue1Jan-Mar2018.pdf.

ECLAC (2020) The climate emergency in Latin America and the Caribbean: The path aheadresignation or action? CEPAL. Available at: https://www.cepal.org/es/publicaciones/45677-laemergencia-cambio-climatico-america-latina-caribe-seguimos-esperando-la (Accessed: 19 July 2020). 
ECLAC and UNHCR (2020) People of African descent in Latin America and the Caribbean: Developing indicators to measure and counter inequalities. Santiago, Chile: United Nations. Available at: https://www.un.org/sites/un2.un.org/files/19-00854_people_of_african_descentweb.pdf.

Ffrench-Davis, R. and Griffith-Jones, S. (2019) 'Financial Globalization and Its Implications for Development', in Nissanke, M. and Ocampo, J. A. (eds) The Palgrave Handbook of Development Economics: Critical Reflections on Globalisation and Development. Cham: Springer International Publishing, pp. 697-726. doi: 10.1007/978-3-030-14000-7_20.

Fine, B. (2012) 'Neoliberalism in Retrospect? It's Financialisation, Stupid', in Kyung-Sup, C., Fine, B., and Weiss, L. (eds) Developmental Politics in Transition: The Neoliberal Era and Beyond. London: Palgrave Macmillan UK (International Political Economy Series), pp. 51-69. doi: 10.1057/9781137028303_4.

Fine, B. and Pollen, G. (2018) 'The Developmental State Paradigm in the age of financialization', Handbook on Development and Social Change. Available at: https://www.elgaronline.com/view/edcoll/9781786431547/9781786431547.00019.xml (Accessed: 25 March 2020).

Fry, M. J. (1978) 'Money and Capital or Financial Deepening in Economic Development?', Journal of Money, Credit and Banking, 10(4), pp. 464-475. doi: 10.2307/1991576.

Gabor, D. (2020) 'The Wall Street Consensus'. University of the West of England, Bristol (UWE Bristol). Available at: https://doi.org/10.31235/osf.io/wab8m (Accessed: 11 August 2020).

Gahman, L. and Thongs, G. (2019) 'Development justice, a proposal: Reckoning with disaster, catastrophe, and climate change in the Caribbean', Transactions of the Institute of British Geographers, n/a(n/a). doi: 10.1111/tran.12369.

Gallagher, K. P. and Kozul-Wright, R. (2019) A New Multilateralism: Geneva Principles for a Global Green New Deal for Shared Prosperity. Global Development Policy Center. Available at: https://www.bu.edu/gdp/files/2019/04/A-New-Multilateralism-GDPC_UNCTAD.pdf (Accessed: 7 February 2020).

García-López, G. A. (2018) 'The Multiple Layers of Environmental Injustice in Contexts of (Un)natural Disasters: The Case of Puerto Rico Post-Hurricane Maria', Environmental Justice, 11(3), pp. 101-108. doi: 10.1089/env.2017.0045.

Gewirtzman, J. et al. (2018) 'Financing loss and damage: reviewing options under the Warsaw International Mechanism', Climate Policy, 18(8), pp. 1076-1086. doi:

10.1080/14693062.2018.1450724.

Ghosh, J. (2015) 'Beyond the Millenium Development Goals: A Southern Perspective on a Global New Deal', Journal of International Development, 27(3), pp. 320-329. doi: https://doi.org/10.1002/jid.3087.

Girishankar, N. (2009) Innovating Development Finance - From Financing Sources To Financial Solutions. The World Bank (Policy Research Working Papers). doi: 10.1596/1813-9450-5111. 
Girvan, N. (2005) 'The search for policy autonomy in the South': Available at: http://digitallibrary.un.org/record/559985 (Accessed: 22 May 2020).

Girvan, N. and Girvan, C. (1973) 'The Development of Dependency Economics in the Caribbean and Latin America: Review and Comparison', Social and Economic Studies, 22(1), pp. 1-33.

Gujba, H. et al. (2012) 'Financing low carbon energy access in Africa', Energy Policy, 47, pp. 71-78. doi: 10.1016/j.enpol.2012.03.071.

Heger, M., Julca, A. and Paddison, O. (2008) Analysing the Impact of Natural Hazards in Small Economies: The Caribbean Case, WIDER Working Paper Series. RP2008-25. World Institute for Development Economic Research (UNU-WIDER). Available at:

https://ideas.repec.org/p/unu/wpaper/rp2008-25.html (Accessed: 19 July 2020).

Hudson, P. J. (2017) Bankers and Empire: How Wall Street Colonized the Caribbean. University of Chicago Press.

IDB (2019) Assessment of the Effects and Impacts of Hurricane Dorian in the Bahamas (Executive Summary). Washington, D.C.: Inter-American Development Bank. Available at: http://idbdocs.iadb.org/wsdocs/getdocument.aspx?docnum=EZSHARE-1256154360-486 (Accessed: 7 February 2020).

IMF (2019) Building Resilience in Developing Countries Vulnerable to Large Natural Disasters. Washington, D.C.: International Monetary Fund. Available at: https://www.imf.org/en/Publications/Policy-Papers/Issues/2019/06/24/Building-Resilience-inDeveloping-Countries-Vulnerable-to-Large-Natural-Disasters-47020 (Accessed: 26 February 2020).

IRENA (2020) Scaling up Renewable Energy Deployment in Africa: Detailed Overview of IRENA's engagement and Impact. Paris, France: International Renewable Energy Agency. Available at: https://www.irena.org/-

/media/Files/IRENA/Agency/Publication/2020/Feb/IRENA_Africa_Impact_Report_2020.pdf?la=e n\&hash=B1AD828DFD77D6430B93185EC90A0D1B72D452CC (Accessed: 20 November 2020).

Jomo, K. S. and Chowdhury, A. (2019) 'World Bank Financializing Development', Development. doi: 10.1057/s41301-019-00206-3.

Kaltenbrunner, A. and Karacimen, E. (2016) 'The contested nature of financialization in emerging capitalist economies', The Great Financial Meltdown. Available at: https://wwwelgaronline-com.ezproxy.uwe.ac.uk/view/edcoll/9781784716486/9781784716486.00026.xml (Accessed: 29 March 2020).

Khan, M. et al. (2019) 'Twenty-five years of adaptation finance through a climate justice lens', Climatic Change. doi: 10.1007/s10584-019-02563-x.

Kvangraven, I. H., Koddenbrock, K. and Sylla, N. S. (2020) 'Financial subordination and uneven financialization in 21st century Africa', Community Development Journal. doi:

$10.1093 / \mathrm{cdj} / \mathrm{bsaa047.}$ 
Lightfoot, N. (2020) 'Disrepair, Distress, and Dispossession: Barbuda after Hurricane Irma', Small Axe, 24(2), pp. 133-146.

Mawdsley, E. et al. (2018) 'Exporting stimulus and "shared prosperity": Reinventing foreign aid for a retroliberal era', Development Policy Review, 36(S1), pp. O25-O43. doi:

https://doi.org/10.1111/dpr.12282.

Mawdsley, E. (2018) "From billions to trillions": Financing the SDGs in a world "beyond aid"', Dialogues in Human Geography, 8(2), pp. 191-195. doi: 10.1177/2043820618780789.

McKinnon, R. I. (2010) Money and Capital in Economic Development. Brookings Institution Press.

Mehta, M., Fugelsnes, T. and Virjee, K. (2005) 'Financing the Millennium Development Goals for Water and Sanitation: What Will it Take?', International Journal of Water Resources Development, 21(2), pp. 239-252. doi: 10.1080/07900620500108445.

Moulton, A. A. and Machado, M. R. (2019) 'Bouncing Forward After Irma and Maria:

Acknowledging Colonialism, Problematizing Resilience and Thinking Climate Justice', Journal of Extreme Events, 06(01), p. 1940003. doi: 10.1142/S2345737619400037.

Multilateral Development Finance Committee (2015) 'From billions to trillions - Transforming development finance post-2015 financing for development: Multilateral Development Finance'. World Bank and International Monetary Fund. Available at:

http://pubdocs.worldbank.org/en/622841485963735448/DC2015-0002-E-

FinancingforDevelopment.pdf (Accessed: 23 November 2020).

Musthaq, F. (2020) 'Development Finance or Financial Accumulation for Asset Managers?: The Perils of the Global Shadow Banking System in Developing Countries', New Political Economy, 0(0), pp. 1-20. doi: 10.1080/13563467.2020.1782367.

Njikam, O. (2017) 'Financial liberalization and growth in African economies: The role of policy complementarities', Review of Development Finance, 7(1), pp. 73-83. doi:

10.1016/j.rdf.2017.02.001.

OECD (2019) Climate Finance Provided and Mobilised by Developed Countries in 2013-17. Organization of Economic Cooperation and Development. Available at:

https://www.oecd.org/environment/cc/Climate-finance-from-developed-to-developing-countriesPublic-flows-in-2013-17.pdf (Accessed: 30 October 2019).

Perry, K. (2020) 'Between the Devil, Debt and the Deep Blue Sea: Why the Global South Needs Reparations for the Climate Crisis - The FinReg Blog', The FinReg Blog, 5 August. Available at: https://sites.law.duke.edu/thefinregblog/2020/08/05/between-the-devil-debt-and-the-deep-bluesea-why-the-global-south-needs-reparations-for-the-climate-crisis/ (Accessed: 17 November 2020).

Perry, K. K. (2020a) 'For politics, people, or the planet? The political economy of fossil fuel reform, energy dependence and climate policy in Haiti', Energy Research \& Social Science, 63, p. 101397. doi: 10.1016/j.erss.2019.101397. 
Perry, K. K. (2020b) 'Structuralism and Human Development: A Seamless Marriage? An Assessment of Poverty, Production and Environmental Challenges in CARICOM Countries', International Journal of Political Economy, 49(3), pp. 222-242. doi:

10.1080/08911916.2020.1824735.

Perry, K. K. (2020c) 'The Triple Crisis of Debt, Demand and Decarbonisation: a preliminary analysis of the impact of COVID-19 on commodity-dependent developing countries', International Journal of Development Issues. doi: 10.1108/IJDI-07-2020-0166.

Pulido, L. (2016) 'Flint, Environmental Racism, and Racial Capitalism', Capitalism Nature Socialism, 27(3), pp. 1-16. doi: 10.1080/10455752.2016.1213013.

Ram, J. and Donna Kaidou-Jeffrey (2020) 'Financing the Blue Economy in the Wider Caribbean', in Clegg, P. et al. (eds) The Caribbean Blue Economy. Abingdon: Routledge (Europa Regional Perspectives), pp. 210-225.

Richards, J.-A. and Schalatek, L. (2018) Not a silver bullet: why a focus on insurance to address loss and damage is a distraction from real solutions. Washington, D.C.

Ritchie, H. and Roser, M. (2017) ' $\mathrm{CO}_{2}$ and Greenhouse Gas Emissions', Our World in Data. Available at: https://ourworldindata.org/co2-and-other-greenhouse-gas-emissions (Accessed: 16 October 2020).

Rodney, W. (1972) How Europe Underdeveloped Africa. East African Publishers.

Saunders, N. (2019) Climate change adaptation finance: are the most vulnerable nations prioritised? Stockholm, Sweden: Stockholm Environemntal Institute. Available at:

https://www.sei.org/publications/climate-adaptation-finance-vulnerable-nations/ (Accessed: 21 February 2020).

Sealey-Huggins, L. (2017) “ $1.5^{\circ} \mathrm{C}$ to stay alive": climate change, imperialism and justice for the Caribbean', Third World Quarterly, 38(11), pp. 2444-2463. doi:

10.1080/01436597.2017.1368013.

Shaw, E. S. (1973) Financial Deepening in Economic Development. Oxford University Press.

Sheller, M. (2018) 'Caribbean futures in the offshore Anthropocene: Debt, disaster, and duration', Environment and Planning D: Society and Space, 36(6), pp. 971-986. doi: $10.1177 / 0263775818800849$.

Sheller, M. (2020) Island Futures: Caribbean Survival in the Anthropocene. Duke University Press.

Shilliam, R. (2014) 'Race and Development', in Weber, H. (ed.) Politics of Development: A Survey. Routledge, pp. 31-48.

Smith-Nonini, S. (2020) 'The Debt/Energy Nexus behind Puerto Rico's Long Blackout: From Fossil Colonialism to New Energy Poverty', Latin American Perspectives, 47(3), pp. 64-86. doi: 10.1177/0094582X20911446. 
Steele, P. and Patel, S. (2020) Tackling the triple crisis. Using debt swaps to address debt, climate and nature loss post-COVID-19. Issue Paper 16674IIED. London, UK: International Institute for Environment and Development (IIED). Available at: https://pubs.iied.org/16674IIED/ (Accessed: 25 November 2020).

Thérien, J.-P. and Pouliot, V. (2020) 'Global governance as patchwork: the making of the Sustainable Development Goals', Review of International Political Economy, 27(3), pp. 612636. doi: 10.1080/09692290.2019.1671209.

Thomas, A. and Benjamin, L. (2018) 'Management of loss and damage in small island developing states: implications for a $1.5^{\circ} \mathrm{C}$ or warmer world', Regional Environmental Change, 18(8), pp. 2369-2378. doi: 10.1007/s10113-017-1184-7.

Thomas, A. and Benjamin, L. (2019) 'Non-economic loss and damage: lessons from displacement in the Caribbean', Climate Policy, 0(0), pp. 1-14. doi:

10.1080/14693062.2019.1640105.

Tilley, L. (2020) 'Extractive investibility in historical colonial perspective: the emerging market and its antecedents in Indonesia', Review of International Political Economy, 0(0), pp. 1-20. doi: 10.1080/09692290.2020.1763423.

Tilley, L. and Shilliam, R. (2018) 'Raced Markets: An Introduction', New Political Economy, 23(5), pp. 534-543. doi: 10.1080/13563467.2017.1417366.

UNCTAD (2018) Trade and Development Report 2018: Power, Platforms and the Free Trade Illusion. Geneva, Switzerland: United Nations. Available at:

https://unctad.org/en/PublicationsLibrary/tdr2018_en.pdf.

UNCTAD (2019) Trade and Development Report 2019: Financing a Green New Deal. Geneva, Switzerland: United Nations. Available at:

https://unctad.org/en/PublicationsLibrary/tdr2019_en.pdf.

UNDP (2018) Regional Overview: Impact of Hurricanes Irma and Maria. New York: United Nations. Available at:

https://www.acaps.org/sites/acaps/files/products/files/acaps_caribbean_response_regional_over view_conference_supporting_document.pdf (Accessed: 17 November 2020).

United Nations (1992) 'Agenda 21', in. United Nations Conference on Environment \& Development Rio de Janerio, Brazil, 3 to 14 June 1992, Rio de Janerio, Brazil: United Nations Sustainable Development. Available at:

https://sustainabledevelopment.un.org/content/documents/Agenda21.pdf.

United Nations (2014) Report of the Intergovernmental Committee of Experts on Sustainable Development Financing. New York: United Nations. Available at: https://www.un.org/esa/ffd/wpcontent/uploads/2014/12/ICESDF.pdf (Accessed: 26 November 2020).

United Nations (2015a) Addis Ababa Action Agenda of the Third International Conference on Financing for Development (Addis Ababa Action Agenda. Addis Ababa, Ethiopia: United Nations. Available at:

https://sustainabledevelopment.un.org/content/documents/2051AAAA_Outcome.pdf (Accessed: 11 August 2020). 
United Nations (2015b) Macroeconomic policy questions: international financial system and development. Report of the Second Committee A/70/470/Add.2. New York: United Nations General Assembly. Available at:

https://www.un.org/ga/search/view_doc.asp?symbol=A/70/470/Add.2\&Lang=E (Accessed: 11 August 2020).

United Nations (2019) Roadmap for Financing the 2030 Agenda for Sustainable Development. New York: United Nations. Available at: https://www.un.org/sustainabledevelopment/wpcontent/uploads/2019/07/UN-SG-Roadmap-Financing-the-SDGs-July-2019.pdf (Accessed: 26 November 2020).

United Nations (2020) Financing for Sustainable Development Report 2020. Report of the Interagency Task Force on Financing for Development. New York: United Nations. Available at: https://developmentfinance.un.org/sites/developmentfinance.un.org/files/FSDR_2020.pdf (Accessed: 22 November 2020).

Vanhala, L. and Hestbaek, C. (2016) 'Framing Climate Change Loss and Damage in UNFCCC Negotiations', Global Environmental Politics, 16(4), pp. 111-129. doi: 10.1162/GLEP_a_00379.

Vos, R. (2017) 'From billions to trillions: towards reform of development finance and the global reserve system', Sustainable Development Goals and Income Inequality. Available at: https://www.elgaronline.com/view/edcoll/9781788110273/9781788110273.00008.xml (Accessed: 23 November 2020).

Welcome, L. A. (2020) 'The Infrastructures of Liberation at the End of the World: A Reflection on Disaster in the Caribbean', Small Axe, 24(2), pp. 96-109. 
i The UN reported that the 'adoption of the 17 global goals at its core, was met with a thunderous standing ovation from delegations that included many of the more than 150 world leaders who will be addressing the Summit'. See: https://www.un.org/sustainabledevelopment/blog/2015/09/historic-newsustainable-development-agenda-unanimously-adopted-by-193-un-members/.

ii The financial liberalization thesis referred to attempts usually through policy and regulation to 'freeing financial markets from any intervention and letting the market determine the allocation of credit' (Arestis and Sawyer, 2005). While authors do not entirely share an agreed definition, Fine (2014) has delineated the financialization as underpinned by the period of global neoliberalism "a complex amalgam of developments within global finance and in its interactions with, and consequences for, economic and social life more generally... it is not merely the expansion and proliferation of financial markets that are striking but also the penetration of such financing into a widening range of both economic and social reproduction - housing, pensions, health..." (Fine, 2012, p. 5). Further, according to Hudson (2017) finance capitalism, emblematic in 'dark finance' that is the propagation of ideological, economic and cultural tropes about Black people's relationship to finance, and propagated by Wall Street in the Caribbean, has underwritten US imperialism, and expressed imperialism's racial and cultural orders.

iii Antoniades et al. (2020)'s paper seeks to estimate how financial crises, regardless of specific types, impact on poverty dynamics in different groups of countries. They classify three types of financial crises: systemic banking, currency, and sovereign debt crises. Banking crises are defined as systemic, when there are significant signs of financial distress in the banking system (e.g. bank runs, bank liquidations, significant losses in the banking system in terms of non-performing loans or total assets) and significant banking policy interventions in response to banking losses. Currency crises are defined as a nominal depreciation of the country's currency vis-à-vis the U.S. dollar of at least 30 per cent that is also at least 10 percentage points higher than the rate of depreciation in the prior year. As for sovereign debt crises, these include episodes of sovereign default or debt restructuring.

iv Climate finance refers to local, national or transnational financing-drawn from public, private and alternative sources of financing-that seeks to support mitigation and adaptation actions that will address climate change. See: https://unfccc.int/topics/climate-finance/the-big-picture/introduction-toclimate-finance.

$\checkmark$ Of the top 10 countries / territories by economic losses as a percentage of GDP, eight of the countries / territories are island nations, seven of those being in the Caribbean region (CRED and UNDRR, 2020).

vi See https://www.ccrif.org/about-us.

vii Scholars show that climate loss and damage made it into the UN Framework on Climate Change in 2013 after much struggle by developing countries through Warsaw International Mechanism on Loss and Damage Associated with Climate Change Impacts (WIM) but this further obscured concerned about liability and compensation held by the so-called developed North as multiple actors have assigned different meanings (Vanhala and Hestbaek, 2016; Thomas and Benjamin, 2018).

viii There remains major data shortcomings on economic losses from disasters especially for lower and middle income countries. Records are particularly incomplete from Africa and South Asia, as only 13\% of 
all disaster events in Africa reported any economic losses and only $23 \%$ of all events in South Asia reported losses (CRED and UNDRR, 2020).

${ }^{\text {ix }}$ Debt for climate and nature swaps are a situation where a creditor allows the debt to be reduced either by conversion to local currency and/or paid at a lower interest rate or some form of debt writeoff - and the money saved is converted to invest in poverty-reducing climate resilience, climate emissions mitigation or biodiversity protection initiatives (Steele and Patel, 2020).

${ }^{x}$ In 2040, it is estimated that the entire African continent would account for almost a quarter of the world's population, but only $6 \%$ of energy demand (BP, 2019).

${ }^{x i}$ Antigua and Barbuda, Anguilla, Bahamas, British Virgin Islands, Cuba, Dominican Republic, Haiti, Puerto Rico, St Barthélemy, St. Martin, Sint Maarten, Turks and Caicos, and the US Virgin Islands were affected. 